\title{
INDIKATOR KEBIJAKAN USAHA PEMBANGUNAN WISATA MASAL DI PULAU-PULAU KECIL
}

\section{Indicators of Mass Tourism Development Policy in Small Islands}

\author{
*Mira \\ Balai Besar Penelitian Sosial Ekonomi Kelautan dan Perikanan \\ JI. KS. Tubun Petamburan VI Jakarta 10260 \\ Telp. (021) 53650162, Fax. (021)53650159 \\ *email: miraclenia@yahoo.com \\ Diterima 25 Januari 2014 - Disetujui 3 Juni 2014
}

\begin{abstract}
ABSTRAK
Tujuan dari penelitian ini adalah menganalisis indikator kebijakan pembangunan wisata masal di pulau-pulau kecil di Kepulauan Seribu, penelitian ini penting dilakukan karena kepulauan kecil yang sangat rentan terhadap pembangunan yang tidak ramah lingkungan. Penelitian ini dilakukan pada tahun 2012 di Kepulauan Seribu, yang dibiayai oleh Universite de La Rochelle. Indikator kebijakan pembangunan wisata masal ini mengacu pada parameter yang telah ditetapkan oleh Weaver (2000), Shaw et william (2002) et Cournoyer (2005). Ditinjau dari indikator kebijakan atraksi, pulau-pulau wisata yang dikelola oleh swasta menerapkan wisata masal, hal ini bisa dilihat dari karakteristik atrakasi (aspek wisata sangat dikomersialkan, bersifat generik, homogen, dan, pembangunan ditujukan secara eklusif untuk kunjungan wisatawan, dengan tipe wisata pantai dan berjemur. Dari indikator kebijakan tekanan, aspek pembangunan wisata yang terlalu komersial di pulau yang dikelola oleh swasta membuat aspek sosial terabaikan. Untuk pulau-pulau yang dikelola oleh masyarakat dan oleh pemerintah, indikator kebijakan wisata masal hanya bisa dilihat dari elemen musim kunjungan dan permintaan, sedangkan dua elemen lainnya (volume dan asal turis), element tersebut tidak ditemukan dalam pengelolaan wisata. Ditinjau dari indikator kebijakan struktur ekonomi, pulau-pulau wisata yang dikelola oleh swasta menerapkan wisata masal, karena pembangunan wisata dilakukan secara ektensif, dan pembangunan wisata memiliki multiplier effect yang rendah terhadap masyarakat. Berbeda dengan pulau-pulau yang dikelola masyarakat lokal yang tidak menerapkan wisata masal, karena pengembangan wisata tidak dilakukan secara ektensif, dan memiliki multiplier effect yang tinggi terhadap masyarakat lokal. Kontrol pemerintah dan masyarakat terhadap aturan pembangunan wisata di pulau yang dikelola oleh swasta sangat lemah.
\end{abstract}

Kata Kunci: wisata masal, indikator, pulau-pulau kecil, atraksi

\begin{abstract}
The purpose of this study is to analyze indicators of mass tourism development in small islands. The study was conducted 2012 at Seribu Archipelago (Pramuka, Panggang, Karya, Bidadari, Ayer besar, Untung Jawa, Onrust, Cipir, Kelor, and Rambut Island). Indicators of mass tourism development policy refer to the parameters set by Weaver (2000), Shaw et William (2002) et Cournoyer (2005). The results of the study analysis indicates, firstly (Policy Indicators Attraction, the islands are managed by private companies, practice the principles of mass tourism, because it is commercial, generic, homogen, and exclusive. Secondly, the islands are managed by government and community local, not practice the principles of mass tourism, because it is not extensive, eclusive, and it has high multiplier effect for local community. the islands are managed by private companies do not involve the local communities. Although it is expected from the management of the tourism development that they should involve the local communities. Control of government and society to the rule of tourist development on the island are managed by the private sector is very weak.
\end{abstract}

Keywords: mass tourism, indicators, small island, attraction 


\section{PENDAHULUAN}

Sebuah konferensi internasional mengenai kaitan perubahan iklim dan pembangunan wisata pada Oktober 2007 yang diadakan oleh Organisanisasi Wisata pada tingkat dunia dan organisasi lainnya. Hasil dari konferensi sepakat bahwa kebijakan pembangunan wisata harus merespon perubahan iklim, dimana sebaiknya pembangunan wisata yang dilakukan harus mengurangi dampak efek gas rumah kaca dengan mengubah model pembangunan wisata dari wisata masal ke wisata yang berkelanjutan (UNWTO, 2005). Penerapan konsep pembangunan yang berkelanjutan, bukan wisata masal, diharapkan akan mengurangi jumlah gas karbon akibat kegiatan transportasi dan hotel dari sektor wisata (Fly et al., 2008), karena itu sebaiknya dibatasi aksesibilitas dan jumlah hotel.

Kebijakan wisata masal (artinya dari segi volume bersifat masif), hanya berorientasi pada aspek ekonomi dan tidak memperhatikan partisipasi masyarakat lokal. Wisata masal merepresentasikan jaringan modal korporasi dunia seperti jaringan Hilton, Le Meridian, dan lain-lain. Sebaliknya kurang memperhatikan ekonomi lokal dengan menggunakan produk impor ketimbang produk lokal. Pembangunan wisata masal dikritik karena banyak yang mengakibatkan kerusakan lingkungan dan mengubah sosial budaya suatu masyarakat lokal (Uyarra et al., 2009).

Prinsip pembangunan wisata masal, menurut pendapat (Weaver, 1991) berhubungan dengan tipe penginapan, pasar wisata, dan struktur ekonomi. Prinsip-prinsip pembangunan wisata masal diterapkan, pada awal pembangunan wisata di Kepulauan Hawai, Kepulauan Komoro, Kepulauan Karibia, dan Kepulauan Baléares (Bardoles, 2008). Hal itu dengan ditandai pembangunan wisata hotel dan restauran kelas dunia. Namun saat ini pemerintahan kepulauan tersebut telah mengubah strategi pembangunannya dari wisata masal ke wisata berkelanjutan, karena mengingat pulau-pulau kecil sangat sensitif terhadap tekanan lingkungan.

Salah satu kebijakan untuk mengelola sebuah tempat wisata yang sangan sensitif terhadap dampak kunjungan wisata (karena berupa pulaupulau kecil) dengan mengurangi akses ke tempat wisata. Dalam lokasi penelitian ini (di Kepulauan Seribu), contohnya Pulau Rambut adalah sebuah taman nasional untuk konservasi burung dan satwa pesisir, sudah ada kebijakan pembatasan jumlah pengunjung dengan berbagai cara misalnya dengan meniadakan jalan, tempat penginapan, sumber air tawar, dan restaurant. Di Kepulauan Seribu lainnya, seperti di Pulau Kelor, Onrust, dan Cipir tidak ada pembangunan hotel dan bungalow untuk menjaga peninggalan bersejarah yang dibangun oleh Belanda dari tekanan pengunjung. Seharusnya kebijakan pembangunan hotel dan penginapan di Pulau Panggang, Pramuka, dan Karya harus dibatasi karena pulau-pulau ini dikelilingi oleh ekosistem terumbu karang yang sangat sensitif terhadap perubahan lingkungan akibat pembangunan wisata. Bagaimana indikator kebijakan pembangunan wisata masal di pulaupulau kecil itulah tujuan dari tulisan ini.

\section{METODOLOGI}

\section{Lokasi dan Waktu Penelitian}

Penelitian ini dilakukan di pulau-pulau kecil, yaitu di Kepulauan Seribu bagian utara diwakili oleh Pulau Pramuka, Pulau Panggang, dan Pulau Karya. sedangkan untuk Kepulauan Seribu bagian selatan diwakili oleh Pulau Untung Jawa, Pulau Kelor, Pulau Onrust, Pulau Cipir, Pulau Bidadari, dan Pulau Ayer Besar. Penelitian ini dilakukan pada tahun 2012 yang dibiayai oleh Universite de La Rochelle (Perancis) melalui program beasiswa.

\section{Jenis dan Sumber Data}

Penelitian ini menggunakan data primer dan data sekunder. Data primer diperoleh melalui wawancara dari pengunjung, Bappeda, Dinas Kelautan dan Perikanan, Dinas Pariwisata, dan stakeholder terkait pengembangan wisata di Kepulauan Seribu. Data sekunder diperoleh dari laporan Bappeda, Laporan Tahunan Dinas Kelautan dan Perikanan, Laporan Tahunan Dinas Pariwisata, dan Buku Kepulauan Seribu Dalam Angka yang dikeluarkan oleh Biro Pusat Statistik Kabupaten Kepulauan Seribu.

\section{Metode Analisis Data}

Sebuah kepulauan merupakan gugusan pulau yang terdiri dari beberapa pulau yang menjadi satu kesatuan entitas dalam aspek ekonomi, politik, dan budaya Bardulet et Sheldon (2008). Banyak pulau-pulau di dunia yang merupakan bagian dari sebuah kepulauan. Pulau-pulau dan kepulauan yang merepresentasikan sebuah keunikan dalam kebijakan pembangunan wisata. Objek penelitian 
kita berbeda dengan Vancouver dan Cairns yang menerapkan wisata masal, Kepulauan Seribu merupakan sebuah kawasan konservasi yang terbentuk dari gugusan pulau kecil yang sangat rawan terhadap aktivitas manusia (pemanfaatan lahan dan polusi).

Menurut Stock et al. (2006), dalam sebuah kawasan wisata yang sangan sensitif terhadap perubahan lingkungan seperti kawasan konservasi, maka sebaiknya ada kebijakan pembatasan frekuensi kunjungan wisata atau dengan kata lain pembangunan wisata tidak bersifat masal. Pembatasan tersebut bisa berupa kebijakan dimana sebuah kawasan wisata dibuat dengan membatasi aksesibilitas, seperti membatasi jumlah parkir. Pembangunan wisata pada kawasan yang rawan terhadap perubahan lingkungan perlu dilakukan kajian yang mendalam antara aktivitas yang dilakukan dan aksesibilitas terhadap kawasan tersebut. Seperti saran Stock (2006) dan Sorupia (2005) yang sepakat bahwa daerah tujuan wisata dalam kawasan konservasi dianjurkan untuk membatasi aksesibilitas. Itulah salah satu alasan kenapa Bakosurtanal tidak memasukan sistem transportasi dalam parameter pendukung untuk pengembangan pariwisata bahari dan pariwisata pantai.

Model pembangunan wisata masal/tidak masal ditentukan oleh beberapa indikator kebijakan dengan melihat 5 aspek.Lima aspek tersebut adalah atraksi, pasar, struktur ekonomi , akomodasi , dan peraturan. Pada model pembangunan wisata masal ini dilakukan secara kualitatif juga dilakukan secara kuantitatif deskriptif. Teknik kualitatif dilakukan dengan mewawancarai responden secara mendalam. Teknik Kuantitatif deskriptif dilakukan dengan kuesioner berupa pilihan yang dibobot. Variabel dari pembangunan wisata masal ini mengacu pada parameter yang telah ditetapkan oleh Weaver (2000), Shaw dan william (2002), dan Cournoyer (2005). Masing-masing dari pembangunan wisata masal bisa dilihat pada tabel 1 di bawah ini:

Tabel 1. Variabel Pembangunan Wisata Masal. Table 1.Variable of Mass Tourism Development.

\begin{tabular}{|c|c|c|c|c|}
\hline \multicolumn{5}{|c|}{ Pembangunan Wisata Masal/ Mass Tourism Development } \\
\hline $\begin{array}{l}\text { Parameter atraksi/ } \\
\text { Attraction parametre }\end{array}$ & $\begin{array}{l}\text { Parameter Pasar/ } \\
\text { Market parametre }\end{array}$ & $\begin{array}{l}\text { Parameter Struktur } \\
\text { Ekonomi/Parametre of } \\
\text { Economic structur }\end{array}$ & $\begin{array}{l}\text { Parameter Akomodasi/ } \\
\text { Accomodation parameter }\end{array}$ & $\begin{array}{l}\text { Parameter peraturan/ } \\
\text { Law parametre }\end{array}$ \\
\hline $\begin{array}{l}\text { Pembangunan wisata } \\
\text { terlalu komersial/ } \\
\text { Comercial }\end{array}$ & $\begin{array}{l}\text { Bersifat masif dan } \\
\text { tur diorganisasi } \\
\text { oleh tur wisata/ } \\
\text { Masif }\end{array}$ & $\begin{array}{l}\text { Sektor wisata } \\
\text { mendominasi } \\
\text { perekonomian/Tourism } \\
\text { sector dominates the } \\
\text { economy }\end{array}$ & $\begin{array}{l}\text { Akomodasi dilakukan } \\
\text { pada skala besar/Large } \\
\text { scale accomodation }\end{array}$ & $\begin{array}{l}\text { Peraturan dikontrol } \\
\text { oleh sektor swasta/ } \\
\text { Law controlled by } \\
\text { private sector }\end{array}$ \\
\hline $\begin{array}{l}\text { Bersifat homogen dan } \\
\text { tidak natural/Homogen }\end{array}$ & $\begin{array}{l}\text { Adanya musim } \\
\text { kunjungan wisata/ } \\
\text { peak/low season }\end{array}$ & $\begin{array}{l}\text { Memiliki hubungan yang } \\
\text { didominasi dari luar/ } \\
\text { Tourism dominated by the } \\
\text { other country }\end{array}$ & $\begin{array}{l}\text { Pembangunan } \\
\text { terkonsentrasi } \\
\text { pada zona wisata/ } \\
\text { Concentracion } \\
\text { developpement on } \\
\text { tourism sector }\end{array}$ & $\begin{array}{l}\text { Kuantitas aturan } \\
\text { yang dibuat sangat } \\
\text { minim dan hanya } \\
\text { mengakomodasi } \\
\text { kepentingan } \\
\text { swasta/ Rules just } \\
\text { accommodate the } \\
\text { private interests }\end{array}$ \\
\hline $\begin{array}{l}\text { Hanya ditujukan eklusif } \\
\text { untuk turisme/Exlusive } \\
\text { for tourisme }\end{array}$ & $\begin{array}{l}\text { Pasar wisata } \\
\text { didominasi turis } \\
\text { asing/Tourism } \\
\text { market dominated } \\
\text { by foreigner }\end{array}$ & Ektensif/Extensive & $\begin{array}{l}\text { Kepadatan } \\
\text { bangunan tinggi/High } \\
\text { accomodation }\end{array}$ & $\begin{array}{l}\text { Menganut idiologi } \\
\text { pasar bebas/Market } \\
\text { free ideology }\end{array}$ \\
\hline $\begin{array}{l}\text { Menjual pantai, } \\
\text { matahari, taman } \\
\text { bermain, dan } \\
\text { peninggalan industri/ } \\
\text { Sun, sea, and beach }\end{array}$ & $\begin{array}{l}\text { Elastis pada } \\
\text { harga/Elasticity of } \\
\text { the price }\end{array}$ & $\begin{array}{l}\text { Multiplier effect sangat } \\
\text { rendah/Low multiplier } \\
\text { effect }\end{array}$ & $\begin{array}{l}\text { Akomodasi memiliki } \\
\text { gaya internasional/ The } \\
\text { accommodation has an } \\
\text { international style }\end{array}$ & $\begin{array}{l}\text { Aturan berorientasi } \\
\text { pada pertumbuhan } \\
\text { ekonomi/ Rule- } \\
\text { oriented economic } \\
\text { growth }\end{array}$ \\
\hline- & - & - & $\begin{array}{l}\text { Akomodasi milik } \\
\text { perusahaan besar } \\
\text { non lokal/Owner of } \\
\text { accomodation is big non } \\
\text { local company }\end{array}$ & - \\
\hline
\end{tabular}

Sumber : Weaver (2000), Shaw dan william (2002), dan Cournoyer (2005)

Source: Weaver (2000), Shaw dan william (2002), dan Cournoyer (2005) 


\section{Indikator Kebijakan Pembangunan Wisata Masal / Non-Masal}

\section{Indikator Kebijakan Dari Parameter Atraksi}

Pulau yang wisatanya dikelola oleh pemerintah adalah Pulau Onrust, Cipir, dan Pulau Kelor dan Pulau Karya), pulau yang wisatanya dikelola oleh swasta adalah Pulau Bidadari dan Pulau Ayer Besar, pulau yang wisatanya dikelola oleh masyarakat adalah Pulau Untung Jawa, Pulau Pramuka, dan Pulau Panggang. Pulau yang dikelola oleh masyarakat lokal tidak menerapkan satu pun dari indikator kebijakan pembangun wisata masal jika dilihat dari parameter atraksi. Variabel dari pembangunan wisata masal ini mengacu pada parameter yang telah ditetapkan oleh Weaver (2000), Shaw dan william (2002), dan Cournoyer (2005). Kebijakan pembangunan wisata tidak terlalu komersial, karakter wisata tidak homegen, generik, dan artifisial. Antara satu pulau pemukiman dengan pulau pemukiman lainnya atraksi wisata yang ditawarkan relatif berbeda, misalnya Pulau Untung Jawa menawarkan atraksi aktivitas bermain di pantai, sedangkan di Pulau Pramuka menawarkan atraksi wisata bawah laut. Pulau-pulau yang dikelola oleh masyarakat lokal tidak hanya ditujukan untuk pembangunan wisata juga ditujukan untuk pembangunan budidaya akuakultur dan pemukiman.

Pada Tabel 2, hal yang sama juga berlaku pada pulau-pulau yang dikelola oleh pemerintah, tidak menerapkan satu pun dari indikator kebijakan pembangun wisata masal jika dilihat dari parameter atraksi. Pembangun di pulau ini untuk melindungi peninggalan sejarah Belanda dan dijadikan atraksi wisata untuk memperkenalkan generasi muda terhadap sejarah penjajahan Belanda (Pulau Onrust, Pulau Cipir, dan Pulau Kelor). Sedangkan pengelolaan pulau Rambut untuk konservasi hewan dan tumbuhan langka, pengunjung yang datang untuk melihat atraksi dari burung, biawak, dan tumbuhan pesisir. Jadi antara satu pulau dengan pulau lain tidak homogen karakternya.

Tabel 2. Indikator Kebijakan Wisata Masal Dari Parameter Atraksi.

Table 2. Mass Tourisme Policy Indicator From Attraction Parametre.

\begin{tabular}{|c|c|c|c|c|}
\hline Elemen/Element & $\begin{array}{c}\text { Karakter dari wisata } \\
\text { masal/Mass tourism } \\
\text { caracter }\end{array}$ & $\begin{array}{l}\text { Pulau-pulau wisata } \\
\text { yang dikelola oleh } \\
\text { swasta /lsland } \\
\text { managed by } \\
\text { private company }\end{array}$ & $\begin{array}{l}\text { Pulau-pulau } \\
\text { wisata yang } \\
\text { dikelola oleh } \\
\text { masyarakat / / } \\
\text { Island managed } \\
\text { by community }\end{array}$ & $\begin{array}{l}\text { Pulau-pulau } \\
\text { wisata yang } \\
\text { dikelola oleh } \\
\text { pemerintah } \\
\text { / /lsland } \\
\text { managed by } \\
\text { government }\end{array}$ \\
\hline Tekanan/Pressure & $\begin{array}{l}\text { Pembangunan wisata } \\
\text { terlalu komersial/ } \\
\text { Commercial tourism } \\
\text { development }\end{array}$ & $\begin{array}{l}\text { Pembangunan } \\
\text { wisata terlalu } \\
\text { komersial*/ }^{*} \text { Commercial tourism } \\
\text { development }\end{array}$ & $\begin{array}{l}\text { Pembangunan } \\
\text { wisata tidak terlalu } \\
\text { komersial* / Not- } \\
\text { comercial tourism } \\
\text { development }\end{array}$ & $\begin{array}{l}\text { Pembangunan } \\
\text { wisata } \\
\text { tidak terlalu } \\
\text { komersial* }^{*} \\
\text { Not-comercial } \\
\text { tourism } \\
\text { development }\end{array}$ \\
\hline Karakter/ Character & $\begin{array}{l}\text { Bersifat homogen dan } \\
\text { tidak natural (karakter } \\
\text { tujuan wisata satu } \\
\text { dengan yang lainnya } \\
\text { sama)/ Homogene and } \\
\text { unnatural }\end{array}$ & $\begin{array}{l}\text { Bersifat homogen } \\
\text { dan generic/ } \\
\text { Homogene and } \\
\text { generic }\end{array}$ & $\begin{array}{l}\text { Heterogen / } \\
\text { Heterogene }\end{array}$ & $\begin{array}{l}\text { Heterogen / } \\
\text { Heterogene }\end{array}$ \\
\hline Orientasi/ Orientation & $\begin{array}{l}\text { Hanya ditujukan eklusif } \\
\text { untuk turisme/ Exlusive } \\
\text { for tourism }\end{array}$ & $\begin{array}{l}\text { Hanya ditujukan } \\
\text { eklusif untuk turisme } \\
\text { / Exlusive for } \\
\text { tourism }\end{array}$ & $\begin{array}{l}\text { Wisata dan } \\
\text { pemukiman/ } \\
\text { Tourism and } \\
\text { settlement }\end{array}$ & $\begin{array}{l}\text { Wisata dan } \\
\text { konservasi/ } \\
\text { Tourism and } \\
\text { conservation }\end{array}$ \\
\hline Jenis/ Type & $\begin{array}{l}\text { Menjual pantai, matahari, } \\
\text { taman bermain, dan } \\
\text { peninggalan industri / } \\
\text { Sun, sea, beach }\end{array}$ & $\begin{array}{l}\text { Menjual pantai, } \\
\text { matahari, taman } \\
\text { bermain/ Sun, sea, } \\
\text { beach }\end{array}$ & $\begin{array}{l}\text { Selam dan } \\
\text { pengamatan } \\
\text { satwa/ Snorkeling }\end{array}$ & $\begin{array}{l}\text { Peninggalan } \\
\text { sejarah/ } \\
\text { Historic tourism }\end{array}$ \\
\hline $\begin{array}{l}\text { Kesimpulan/ } \\
\text { Conclusion }\end{array}$ & & $\begin{array}{l}\text { Wisata masal/ Mass } \\
\text { tourism }\end{array}$ & $\begin{array}{l}\text { Wisata non-masal } \\
\text { / Non-mass } \\
\text { tourism }\end{array}$ & $\begin{array}{l}\text { Wisata non- } \\
\text { masal / Non- } \\
\text { mass tourism }\end{array}$ \\
\hline
\end{tabular}

Sumber : Pengamatan, wawancara dan Analisa peneliti, 2012/Source : Observation, interview and data processed, 2012

Ket: * Dilakukan dengan kuantitatif deskriptif dengan pembobotan 
Ditinjau dari indikator kebijakan parameter atraksi, pulau-pulau wisata yang dikelola oleh swasta menerapkan wisata masal, hal ini bisa dilihat dari elemen atraksi (tekanan, karakter, orientasi, dan tipe wisata) dan karakteristik atrakasi (aspek wisata sangat dikomersialkan, bersifat generik, homogen, dan artifisial, pembangunan ditujukan secara eklusif untuk kunjungan wisatawan, dengan tipe wisata pantai, berjemur, dan taman bertema). Pulau Bidadari dan Ayer Besar hanya ditujukan untuk aktivitas wisata, karena pemilik pulau berinvestasi di pulau ini untuk pembangunan wisata, bukan untuk aktivitas pemukiman apalagi aktivitas konservasi. Okupasi lahan ditujukan untuk kenyamanan aktivitas pengunjung, seperti kolam renang, taman bermain, heliport, restauran, dan penginapan.

Dari sisi tekanan, aspek pembangunan wisata yang terlalu komersial di pulau yang dikelola oleh swasta membuat aspek sosial terabaikan. Pengabaian aspek sosial bisa dilihat dari minimnya keterlibatan masyarakat lokal dalam pembangunan. Pemilik pulau sekaligus pemilik hotel dan restaurant lebih suka merekrut karyawan non lokal, karena minimnya tingkat pendidikan dan tidak adanya pengalaman di bidang jasa wisata. Tujuan utama wisata di pulau ini untuk memperoleh penghasilan yang besar dan menekan biaya, penekanan biaya itu bisa dilihat tidak adanya instalasi pengolahan limbah, sehingga limbah domestik dibuang secara langsung ke laut. Dari sisi karakter wisata, pulaupulau wisata yang dikelola oleh swasta bersifat generik, homegen, dan artifisial. Hal ini bisa dilihat dari atraksi yang ditawarkan bersifat homogen (aktivitas bermain di pantai, berenang, outbond, dan jet ski).

\section{Indikator Kebijakan Dari Parameter Pasar}

Dari indikator kebijakan pasar, empat elemen yang dimiliki (volume, musim kunjungan, asal turis, dan permintaan) mengindikasikan pulau-pulau yang dikelola oleh perusahaan swasta menerapkan pengembangan wisata masal. Kita bisa melihat pengelolaan wisata yang bersifat masal dari karakteristik yang dimiliki, seperti dimana berorientasi pada volume yang tinggi dan paket wisata diselenggarakan oleh operator tur, adanya frekuensi musiman, asal wisata pada umumnya didominasi oleh turis asing, dan permintaan adalah elastis terhadap harga. Pada Tabel 3, orientasi pada volume yang tinggi karena perusahaan swasta yang mengelola pulau ini menginginkan memperoleh keuntungan yang besar, karena mereka sudah mengeluarkan biaya yang besar dalam membangun infrastruktur pulau tersebut.

Tabel 3. Indikator Kebijakan Wisata Masal Dari Parameter Pasar.

Table 3. Mass Tourisme Policy Indicator From Market Parametre.

\begin{tabular}{|c|c|c|c|c|}
\hline Elemen/element & $\begin{array}{c}\text { Karakter dari wisata } \\
\text { masal/mass tourism } \\
\text { caracter }\end{array}$ & $\begin{array}{l}\text { Pulau-pulau wisata } \\
\text { yang dikelola oleh } \\
\text { swasta lisland } \\
\text { managed by private } \\
\text { company }\end{array}$ & $\begin{array}{l}\text { Pulau-pulau } \\
\text { wisata yang } \\
\text { dikelola oleh } \\
\text { masyarakat / } \\
\text { Island managed } \\
\text { by community } \\
\end{array}$ & $\begin{array}{c}\text { Pulau-pulau wisata } \\
\text { yang dikelola } \\
\text { oleh pemerintah / } \\
\text { island managed by } \\
\text { goverment }\end{array}$ \\
\hline Volume/ Volume & $\begin{array}{l}\text { Bersifat masif dan } \\
\text { tur diorganisasi oleh } \\
\text { tur wisata / Massif, } \\
\text { organized by tour travel }\end{array}$ & $\begin{array}{l}\text { Tur diorganisasi oleh } \\
\text { tur wisata/ Massif, } \\
\text { organized by tour } \\
\text { travel }\end{array}$ & $\begin{array}{l}\text { Tur tidak } \\
\text { diorganisasi } \\
\text { oleh tur wisata/ } \\
\text { Organized by } \\
\text { community }\end{array}$ & $\begin{array}{l}\text { Tur tidak } \\
\text { diorganisasi oleh tur } \\
\text { wisata/ Non-massif }\end{array}$ \\
\hline $\begin{array}{l}\text { Frekuensi } \\
\text { musiman/ Peak or } \\
\text { low season }\end{array}$ & $\begin{array}{l}\text { Adanya musim } \\
\text { kunjungan wisata / Peak } \\
\text { or low season }\end{array}$ & $\begin{array}{l}\text { Adanya musim } \\
\text { kunjungan wisata } \\
\text { (saat musim libur)/ } \\
\text { Peak season or low } \\
\text { season }\end{array}$ & $\begin{array}{l}\text { Setiap minggu/ } \\
\text { Weekly }\end{array}$ & $\begin{array}{l}\text { Setiap minggu/ } \\
\text { Weekly }\end{array}$ \\
\hline Asal/ Origin & $\begin{array}{l}\text { Pasar wisata didominasi } \\
\text { turis domestik/ } \\
\text { internasional/ Foreigner } \\
\text { or domestic }\end{array}$ & $\begin{array}{l}\text { Asing/ Foreigner } \\
\text { tourists }\end{array}$ & Lokal/ Local & lokal/ Local \\
\hline $\begin{array}{l}\text { Permintaan/ } \\
\text { Demand }\end{array}$ & $\begin{array}{l}\text { Elastis pada harga / } \\
\text { Elasticity of the price }\end{array}$ & $\begin{array}{l}\text { Elastis pada harga / } \\
\text { Elasticity of the price }\end{array}$ & $\begin{array}{l}\text { Elastis pada harga } \\
\text { / Elasticity of the } \\
\text { price }\end{array}$ & $\begin{array}{l}\text { Elastis pada harga / } \\
\text { Elasticity of the price }\end{array}$ \\
\hline $\begin{array}{l}\text { Kesimpulan/ } \\
\text { Conclusion }\end{array}$ & & $\begin{array}{l}\text { Wisata masal / Mass } \\
\text { tourism }\end{array}$ & $\begin{array}{l}\text { Wisata non-masal / } \\
\text { Mass tourism }\end{array}$ & $\begin{array}{l}\text { Wisata non-masal/ } \\
\text { Mass tourism }\end{array}$ \\
\hline
\end{tabular}

Sumber : Pengamatan, wawancara dan Analisa peneliti, 2012

Source : Observation, interview and data processed, 2012 
Turis asing yang mendominasi pulau yang dikelola swasta, karena untuk mengunjungi pulau ini membutuhkan biaya yang tinggi, sehingga turis lokal tidak mampu mengunjungi pulau ini. Seperti yang diungkapkan sebelumnya, mengunjungi pulau ini tanpa mengikuti tur wisata adalah sangat sulit, karena tidak adanya transportasi umum yang mengantarkan turis ke pulau ini, karena itu pada umumnya turis menggunakan paket wisata yang ditawarkan oleh agen wisata. Selain itu, turis lokal kalangan menengah kurang mampu mengunjugi pulau yang dikelola swasta, karena tingginya biaya yang dibutuhkan. Tiket masuk ke pulau ini sekitar Rp 50.000 dan biaya penginapan sekitar Rp 600.000 per malam.

Untuk mengunjungi pulau yang dikelola oleh swasta, pengunjung harus berhubungan dengan agen wisata. Agen wisata ini pada umumnya membuat paket sehari perjalanan, untuk Pulau Bidadari sebesar Rp 250.000 dan Rp 300.000 untuk Pulau Ayer Besar. Pulau Bidadari lebih murah ketimbang Pulau Ayer besar, karena jarak Pulau Ayer Besar lebih jauh dan fasilitasnya lebih lengkap terutama untuk permainan Jet ski. Pulau yang dikelola oleh pemerintah, seperti Pulau Onrust, Kelor, dan Cipir, hanya membutuhkan Rp 75.000 untuk perjalanan sehari. Sedangkan pulau yang dikelola oleh masyarakat, membutuhkan dana sebesar Rp 350.000 untuk pergi ke Pulau Pramuka, karena akan memakan waktu dua hari (karena jaraknya yang jauh dan aktivitas selam yang membutuhkan waktu).

Pada Tabel 4, biaya perjalanan untuk berwisata ke pulau yang dikelola oleh pemerintah seperti Pulau Onrust, Cipir, dan Kelor lebih murah ketimbang pulau yang dikelola oleh swasta. Hal ini disebabkan pengunjung dapat menggunakan transportasi umum (Rp 30.000 - 35.000), selain itu juga berkunjung ke pulau yang dikelola oleh pemerintah tidak ada tiket masuk, kecuali ingin berkunjung ke Pulau Onrust (Rp 2.000). Lihat perbandingan tiket masuk ke pulau yang dikelola oleh swasta sebesar Rp 50.000 (Pulau Bidadari dan Pulau Ayer besar). Pengunjung yang ingin pergi ke pulau yang dikelola oleh swasta harus menggunakan kapal yang disediakan oleh agen wisata, dimana harganya antara Rp 2 - 8 juta. Bandingkan dengan pergi ke pulau yang dikelola oleh pemerintah, pengunjung dapat menggunakan kapal nelayan dari Tanjung Pasir hanya menyewa kapal sebesar Rp 600.000.

Saat musim tertentu, pulau Bidadari dan Ayer Besar banyak dikunjungi oleh turis, misalnya pada saat liburan sekolah. Tingginya tingkat kunjungan pada musim tertentu adalah merupakan salah satu karakter wisata masal, bahkan pada saat tertentu tingkat kunjungan bisa melebihi daya dukung lingkungan. Berdasarkan wawancara yang dilakukan pada Bulan Maret, 100-200 turis mengunjungi Pulau Bidadari dan Ayer Besar saat-saat musim libur. Akan tetapi, pada saat-saat bukan masa liburan jumlah pengunjung hanya 50 100 pengunjung. Padahal daya dukung lingkungan pulau Bidadari dan Pulau Ayer besar, masingmasing hanya 50 dan 30 turis untuk kategori rendah,

Untuk pulau-pulau yang dikelola oleh masyarakat dan oleh pemerintah,indikator kebijakan wisata masal hanya bisa dilihat dari elemen musim kunjungan dan permintaan, sedangkan dua elemen lainnya (volume dan asal turis), element tersebut tidak ditemukan dalam pengelolaan wisata. Pada umumnya turis yang berkunjung ke pulau yang dikelola oleh pemerintah dan oleh masyarakat adalah turis lokal, dan di kedua pulau ini pengelolaan

Tabel 4. Perbandingan Biaya Perjalanan di Kepulauan Seribu.

Table 4.Comparison of Travel Cost at Seribu Archipelago.

\begin{tabular}{|c|c|c|c|c|}
\hline $\begin{array}{l}\text { Pengelola / } \\
\text { Organized by }\end{array}$ & $\begin{array}{c}\text { Biaya Transportasi / } \\
\text { Transportation cost (Rp /IDR) }\end{array}$ & $\begin{array}{c}\text { Biaya Penginapan / } \\
\text { Accomodation cost (Rp } \\
\text { / IDR) }\end{array}$ & $\begin{array}{c}\text { Tur Wisata I } \\
\text { Travel cost (Rp } \\
\text { / IDR) }\end{array}$ & $\begin{array}{l}\text { Tiket Masuk } \\
\text { ITicket (Rp / } \\
\text { IDR) }\end{array}$ \\
\hline $\begin{array}{l}\text { Swasta/ Private } \\
\text { company }\end{array}$ & $2,000,000-8,000,000($ Yacht $)$ & 600,000 & $\begin{array}{r}250,000- \\
300,000 \text { (sehari/ } \\
\text { Day) }\end{array}$ & 50,000 \\
\hline $\begin{array}{l}\text { Masyarakat/ } \\
\text { Community }\end{array}$ & $\begin{array}{r}30,000-35,000 \text { (Kapal umum } \\
\text { / Boat) }\end{array}$ & $50,000-350,000$ & $\begin{array}{r}350,000 \text { (2 hari / } 2 \\
\text { days })\end{array}$ & Gratis / Free \\
\hline $\begin{array}{l}\text { Pemerintah/ } \\
\text { Government }\end{array}$ & $\begin{array}{r}600,000 \text { (Menyewa kapal } \\
\text { nelayan / Boat rent) }\end{array}$ & $\begin{array}{r}\text { Tidak ada hotel / No- } \\
\text { existing hotel }\end{array}$ & $\begin{array}{r}75,000 \text { (1 hari/ } \\
\text { Day) }\end{array}$ & 2,000 \\
\hline
\end{tabular}

Sumber : Pengamatan, Wawancara dan Analisa Peneliti, 2012

Source : Observation, Interview and Data Processed, 2012 
wisata tidak berorientasi pada volume. Pengelolaan wisata di pulau yang dikelola oleh pemerintah untuk mengenalkan peninggalan sejarah ke generasi muda. Pengelolaan wisata yang dikelola oleh masyarakat lokal untuk meningkatkan pendapatan masyarakat.

\section{Indikator Kebijakan Dari Parameter Struktur Ekonomi}

Ditinjau dari indikator kebijakan struktur ekonomi, pulau-pulau wisata yang dikelola oleh swasta menerapkan wisata masal, hal ini bisa dilihat dari elemen struktur ekonomie (peranan sektor wisata terhadap ekonomi lokal, kerjasama, sifat pembangunan wisata, dan multiplier effect). Keempat elemen tersebut memiliki karakter dimana sektor wisata mendominasi perekonomian, kerja sama ekonomi dilakukan dengan pihak di luar kepulauan Seribu (yaitu berasal dari Jakarta). Pembangunan wisata dilakukan secara ektensif, dan pembangunan wisata memiliki multiplier effect yang rendah terhadap masyarakat

Pada Tabel 5, di pulau-pulau yang dikelola oleh swasta dan milik pribadi, dampak pembangunan wisata tidak dirasakan oleh masyarakat. Pulau ini adalah milik konglemarat atau pejabat publik Indonesia,dimana ia mengelola sendiri pembangunan wisatanya dan jarang merekrut masyarakat lokal. Masyarakat lokal direkrut hanya untuk posisi kelas rendah seperti satpam dan pembersih. Para konglomerat dan pejabat Indonesia pada umumnya berasal dari Jakarta dan berasal dari luar pulau.

Berbeda dengan pulau-pulau yang dikelola masyarakat lokal yang tidak menerapkan wisata masal. Hal ini bisa dilihatindikator kebijakan struktur ekonomi yang dimilikinya, yaitu sektor wisata tidak mendominasi perekonomian lokal, kerja sama wisata dilakukan dengan masyarakat lokal, pengembangan wisata tidak dilakukan secara ektensif, dan memiliki multiplier effect yang tinggi terhadap masyarakat lokal. Sebelumnya, sektor yang mendominasi perekomian pulau-pulau ini adalah sektor perikanan, namun dari tahun ke tahun stok perikanan semakin menurun. Tingkat kunjungan wisata ke pulau yang dikelola oleh masyarakat, membuat mata pencarian masyarakat semakin beragam selain nelayan, seperti penjual makanan, pemilik penginapan, penjual souvenir, dan lain-lain

Tabel 5. Indikator Kebijakan Wisata Masal Dari Struktur Ekonomi.

Table 5. Mass Tourisme Policy Indicator From Structure Economic Parametre.

\begin{tabular}{|c|c|c|c|c|}
\hline Elemen/element & $\begin{array}{c}\text { Karakter dari wisata } \\
\text { masal/Mass tourism } \\
\text { caracter }\end{array}$ & $\begin{array}{l}\text { Pulau-pulau wisata } \\
\text { yang dikelola oleh } \\
\text { swasta /island } \\
\text { managed by } \\
\text { private company }\end{array}$ & $\begin{array}{l}\text { Pulau-pulau } \\
\text { wisata yang } \\
\text { dikelola oleh } \\
\text { masyarakat/ } \\
\text { Island managed } \\
\text { by community }\end{array}$ & $\begin{array}{c}\text { Pulau-pulau wisata } \\
\text { yang dikelola } \\
\text { oleh pemerintah / } \\
\text { Island managed by } \\
\text { goverment }\end{array}$ \\
\hline $\begin{array}{l}\text { Peran sektor wisata/ } \\
\text { Role of tourism sector }\end{array}$ & $\begin{array}{l}\text { Sektor wisata } \\
\text { mendominasi } \\
\text { perekonomian/ } \\
\text { Tourism sector } \\
\text { dominates the } \\
\text { economy }\end{array}$ & $\begin{array}{l}\text { Sektor wisata } \\
\text { mendominasi } \\
\text { perekonomian } \\
\text { pulau / Tourism } \\
\text { sector dominates } \\
\text { the economy }\end{array}$ & $\begin{array}{l}\text { Sektor perikanan } \\
\text { dan wisata / } \\
\text { Fishery and } \\
\text { tourism }\end{array}$ & $\begin{array}{l}\text { Sektor wisata } \\
\text { tidak mendominasi } \\
\text { perekonomian pulau } \\
\text { /Tourism sector } \\
\text { not dominates the } \\
\text { economy }\end{array}$ \\
\hline Aliansi/Alliance & $\begin{array}{l}\text { Memiliki hubungan } \\
\text { yang didominasi } \\
\text { dari luar / Tourism } \\
\text { dominated by the } \\
\text { other island }\end{array}$ & $\begin{array}{l}\text { Jaringan dimiliki } \\
\text { oleh non lokal / } \\
\text { Tourism dominated } \\
\text { by the other island }\end{array}$ & $\begin{array}{l}\text { Jaringan } \\
\text { dimiliki oleh } \\
\text { lokal / Tourism } \\
\text { dominated by } \\
\text { local }\end{array}$ & $\begin{array}{l}\text { Jaringan dimiliki } \\
\text { oleh pemerintah } \\
\text { dan lokal / Tourism } \\
\text { dominated by local } \\
\text { and goverment }\end{array}$ \\
\hline $\begin{array}{l}\text { Dilakukan/ } \\
\text { Developement }\end{array}$ & Ektensif/ Extensive* & Ektensif/ Extensive* & $\begin{array}{l}\text { Non -Ektensif / } \\
\text { Non-Extensive* }\end{array}$ & $\begin{array}{l}\text { Non-Ektensif/ Non- } \\
\text { Extensive* }\end{array}$ \\
\hline Multiplier effect & $\begin{array}{l}\text { Multiplier effect } \\
\text { sangat rendah / Low } \\
\text { multiplier effect* }\end{array}$ & $\begin{array}{l}\text { Rendah / Low } \\
\text { multiplier effect* }\end{array}$ & $\begin{array}{l}\text { Sangat tinggi / } \\
\text { High multiplier } \\
\text { effect* }^{*}\end{array}$ & $\begin{array}{l}\text { Rendah / Low } \\
\text { multiplier effect* }\end{array}$ \\
\hline $\begin{array}{l}\text { Kesimpulan/ } \\
\text { Conclusion }\end{array}$ & & $\begin{array}{l}\text { Wisata masal/ Mass } \\
\text { tourism }\end{array}$ & $\begin{array}{l}\text { Wisata non- } \\
\text { masal/ Non-mass } \\
\text { tourism }\end{array}$ & $\begin{array}{l}\text { Wisata non-masal / } \\
\text { Non-mass tourism }\end{array}$ \\
\hline
\end{tabular}

Sumber : Pengamatan, Wawancara dan Analisa Peneliti, 2012/Source : Observation, Interview and Data Processed, 2012 Ket: * Dilakukan dengan kuantitatif deskriptif dengan pembobotan 
Pada pulau yang dikelola oleh pemerintah dan masyarakat lokal, masyarakat dapat merasakan dampak pembangunan wisata. Hal ini bisa dilihat pembangunan usaha kecil lokal, muncul aktivitas baru untuk mendukung sektor wisata seperti penjual souvenir dan guide, dan munculnya usaha informal seperti pedagang asongan yang menjajakan makanan ke pengunjung. Bahkan ada juga nelayan yang berganti profesi pada saat tertentu mengantarkan pengunjung ke tempat penyelam. Hampir sama dengan pulau-pulau yang dikelola masyarakat lokal, pulau-pulau yang dikelola pemerintah juga tidak menerapkan wisata masal, tapi ada satu elemen wisata masal yang eksis di pulau ini, yaitu sektor pariwisata mendominasi perekonomian lokal.

\section{Indikator Kebijakan Dari Parameter Penginapan}

Ditinjau dari indikator kebijakan penginapan, pulau-pulau wisata yang dikelola oleh swasta menerapkan sedikit karakter dari wisata masal, hal ini bisa dilihat dari 5 elemen penginapan wisata masal, pulau-pulau ini menerapkan 3 elemen, yaitu (ukuran, organisasi penginapan dalam wilayah, dan pemilik). Ketiga elemen itu memiliki karakter pembangunan penginapan dilakukan dalam skala besar, terkosentrasi pada wilayah wisata, dan penginapapan tersebut pada umumnya dimiliki oleh pemilik yang bukan merupakan penduduk lokal dari Kepulauan Seribu. Pemilik penginapan di pulau wisata yang dikelola oleh swasta adalah pemilik pulau itu sendiri, dimana pemilik pulau swasta pada umumnya bukan penduduk lokal, tetapi adalah pengusaha dari Jakarta.

=Sedangkan untuk dua indikator kebijakan, yaitu bentuk arsitektur dan kepadatan penginapan, pengelolaan pulau wisata oleh swasta tidak mengindikasikan pengelolaan wisata masal, dimana tingkat kepadatan penginapan adalah tidak tinggi dan bentuk arsitektur bangunan yang masih menggunakan arsitektur tradisional. Penginapan, restaurant, di Pulau yang dikelola swasta (Pulau Bidadari dan Ayer Besar), pada umumnya terbuat dari kayu. Bahan bangunan ini dipilih karena arsitektur seperti ini sangat disukai pengunjung yang pada umumnya berasal dari luar negeri atau dari wisatawan domestik yang berasal dari kalangan menengah ke bawah, yang menginginkan suasana pedesaan bukan perkotaan. Padahal menurut pengelola, perawatan bangunan yang menggunakan kayu ini sangat besar, apalagi penginapan kayu dibangun langsung di atas permukaan laut. Lagipula penginapan kayu ini sangat rentan terhadap serangan rayap.

Kesamaan antara pemilik penginapan dengan pemilik pulau ini, membuat tidak ada pilihan lain bagi pengunjung dalam memilih penginapan, hal inilah yang menyebabkan harga penginapan di pulau ini lebih mahal ketimbang penginapan di pulau-pulau yang dikelola oleh masyarakat. Di pulau yang dikelola oleh perusahaan swasta turis tidak bisa memilih penginapan, karena memakai sistem monopoli. Sedangkan di pulau-pulau yang dikelola oleh masyarakat, pengunjung bisa memilih tipe penginapan yang sesuai dengan keinginan mereka, karena banyak tipe penginapan yang ditawarkan. Tapi karena pengunjung di pulau-pulau yang dikelola oleh perusahaan swasta merupakan turis asing, jadi harga sebesar Rp 600 ribu per malam, bukan termasuk mahal bagi mereka. Bagi turis domestik kalangan menengah ke bawah apalagi turis lokal, harga ini sangat mahal bagi mereka, hal ini jugalah yang membatasi kunjungan mereka ke pulau yang dikelola oleh swasta.

Pengunjung lokal meminta kepada pemerintah dan pengelola pulau untuk menurunkan harga hotel dan biaya masuk ke pulau yang dikelola oleh pemerintah. Menurut mereka harga tiket masuk sebesar Rp 50.000 dan harga hotel yang sebesar Rp 600.000 adalah harga yang tidak masuk akal. Tapi, pengelola pulau beralasan, harga tersebut mahal karena besarnya biaya investasi yang telah dikeluarkan dalam mengelola sebuah pulau kecil untuk tujuan wisata. Untuk mengelola suatu wisata di pulau-pulau kecil pengusaha harus membangun darmaga, jalan, dan jaringan listrik dengan sendiri. Selain itu mereka juga harus membayar biaya sewa pulau kepada pemerintah.

Pengunjung lokal juga berharap ada transportasi umum yang melayani pengunjung ke pulau yang dikelola oleh perusahaan swasta. Menurut masyarakat lokal dari Kepulauan Seribu, dulu ada kapal pemerintah yang melayani turis untuk berkunjung ke pulau yang dikelola oleh perusahaan swasta. Namun sekarang kapal tersebut hanya melayani pengunjung yang ingin pergi ke pulau-pulau yang ada penduduknya (Pulau Pramuka, Pulau Tidung, Pulau Untung Jawa, Pulau Kelapa, dan Pulau Harapan). Menurut pemerintah, penghentian pelayanan transportasi tersebut karena banyaknya subsidi yang ditanggung oleh pemerintah, padahal mereka yang berkunjung ke pulau tersebut pada umumnya adalah turis asing dan orang kaya. 
Tabel 6. Indikator Kebijakan Wisata Masal Dari Parameter Penginapan. Table 6. Mass Tourisme Policy Indicator From Attraction Parameter.

\begin{tabular}{|c|c|c|c|c|}
\hline $\begin{array}{l}\text { Elemen/ } \\
\text { Element }\end{array}$ & $\begin{array}{c}\text { Karakter dari wisata } \\
\text { masal/ Mass Tourism } \\
\text { Caracter }\end{array}$ & $\begin{array}{l}\text { Pulau-pulau wisata } \\
\text { yang dikelola oleh } \\
\text { swasta / Island } \\
\text { Managed by } \\
\text { Private Company }\end{array}$ & $\begin{array}{l}\text { Pulau-pulau } \\
\text { wisata yang } \\
\text { dikelola oleh } \\
\text { masyarakat / } \\
\text { Island Managed } \\
\text { by Community } \\
\end{array}$ & $\begin{array}{l}\text { Pulau-pulau wisata } \\
\text { yang dikelola } \\
\text { oleh pemerintah / } \\
\text { Island Managed by } \\
\text { Goverment }\end{array}$ \\
\hline Ukuran/Size & $\begin{array}{l}\text { Penginapan dibuat } \\
\text { pada skala besar/ Large } \\
\text { scale accommodation* }\end{array}$ & $\begin{array}{l}\text { Penginapan } \\
\text { dibuat pada skala } \\
\text { besar/ Large scale } \\
\text { accommodation* }\end{array}$ & $\begin{array}{l}\text { Penginapan } \\
\text { dibuat pada skala } \\
\text { kecil/ Small scale } \\
\text { accommodation* }\end{array}$ & $\begin{array}{l}\text { Tidak ada penginapan/ } \\
\text { No existing } \\
\text { accommodation* }\end{array}$ \\
\hline $\begin{array}{l}\text { Organisasi } \\
\text { wilayah/Region } \\
\text { organization }\end{array}$ & $\begin{array}{l}\text { Pembangunan } \\
\text { terkonsentrasi } \\
\text { pada zona wisata/ } \\
\text { Concentration } \\
\text { development on tourism } \\
\text { sector }\end{array}$ & $\begin{array}{l}\text { Pembangunan } \\
\text { terkonsentrasi } \\
\text { pada zona wisata/ } \\
\text { Concentration } \\
\text { development on } \\
\text { tourism sector }\end{array}$ & $\begin{array}{l}\text { Pembangunan } \\
\text { tidak } \\
\text { terkonsentrasi } \\
\text { pada zona wisata/ } \\
\text { Concentration } \\
\text { development } \\
\text { on fishery and } \\
\text { tourism sector }\end{array}$ & $\begin{array}{l}\text { Pembangunan } \\
\text { tidak terkonsentrasi } \\
\text { pada zona wisata/ } \\
\text { Concentration } \\
\text { development on } \\
\text { tourism sector and } \\
\text { conservation }\end{array}$ \\
\hline $\begin{array}{l}\text { Kepadatan/ } \\
\text { Density }\end{array}$ & $\begin{array}{l}\text { Kepadatan } \\
\text { bangunan tinggi/High } \\
\text { Accommodation* }\end{array}$ & $\begin{array}{l}\text { Kepadatan } \\
\text { bangunan } \\
\text { tinggi/ High } \\
\text { accommodation* }\end{array}$ & $\begin{array}{l}\text { Kepadatan } \\
\text { bangunan } \\
\text { tinggi/ High } \\
\text { accommodation* }\end{array}$ & $\begin{array}{l}\text { Kepadatan bangunan } \\
\text { rendah/ No-existing } \\
\text { accommodation* }\end{array}$ \\
\hline $\begin{array}{l}\text { Arsitektur/ } \\
\text { Architectur }\end{array}$ & $\begin{array}{l}\text { Akomodasi memiliki } \\
\text { gaya internasional/ The } \\
\text { accommodation has an } \\
\text { international style }\end{array}$ & $\begin{array}{l}\text { Bergaya tradisional/ } \\
\text { The accommodation } \\
\text { has a local style }\end{array}$ & $\begin{array}{l}\text { Bergaya } \\
\text { tradisional dan } \\
\text { internasional/ The } \\
\text { accommodation } \\
\text { has an } \\
\text { international style } \\
\text { and local style }\end{array}$ & $\begin{array}{l}\text { Bangunan peninggalan } \\
\text { Belanda/ Historic }\end{array}$ \\
\hline Pemilik/Owner & $\begin{array}{l}\text { Akomodasi milik } \\
\text { perusahaan besar } \\
\text { non lokal / Owner of } \\
\text { accomodation is big non } \\
\text { local company }\end{array}$ & $\begin{array}{l}\text { Akomodasi milik } \\
\text { perusahaan besar } \\
\text { non lokal / Owner of } \\
\text { accomodation is big } \\
\text { non local company }\end{array}$ & $\begin{array}{l}\text { Akomodasi milik } \\
\text { perusahaan kecil } \\
\text { lokal/ Owner of } \\
\text { accomodation is } \\
\text { community }\end{array}$ & $\begin{array}{l}\text { Tidak ada penginapan/ } \\
\text { No-existing } \\
\text { accomodation }\end{array}$ \\
\hline $\begin{array}{l}\text { Kesimpulan/ } \\
\text { Conclusion }\end{array}$ & & $\begin{array}{l}\text { Wisata masal/ Mass } \\
\text { tourism }\end{array}$ & $\begin{array}{l}\text { Wisata non- } \\
\text { masal/ Non-mass } \\
\text { tourism }\end{array}$ & $\begin{array}{l}\text { Wisata non-masal/ } \\
\text { Non-mass tourism }\end{array}$ \\
\hline
\end{tabular}

Sumber : Pengamatan, Wawancara dan Analisa Peneliti, 2012/Source : Observation, Interview and Data Processed, 2012 Ket: * Dilakukan dengan kuantitatif deskriptif dengan pembobotan

Untuk pulau-pulau yang dikelola oleh masyarakat lokal, dari 5 indikator kebijakan wisata masal dari sisi penginapan, pada pulau-pulau ini hanya eksis satu indikator kebijakan saja yaitu kepadatan akomodasi yang termasuk pada kategori tinggi. Ada beberapa bangunan akomodasi yang memiliki bentuk arsitektur internasional. Beberapa pemilik akomodasi yang diwawancarai, pemilihan arsitektur non lokal (minimalis) karena mudah dalam biaya perawatan. Selain itu, berbeda dengan turis asing yang berkunjung ke pulau yang dikelola swasta menyukai arsitektur tradisional, wisatawan yang berkunjung ke pulau yang dikelola oleh masyarakat lebih menyukai arsitektur minimalis. Wisatawan yang berkunjung ke pulau yang dikelola oleh masyarakat pada umumnya berasal dari kalangan menengah dan berasal dari Jabodetabek. Penginapan di pulau ini umumnya dimiliki oleh penduduk lokal, bukan dari pengusaha yang berasal dari luar pulau.

\section{Indikator Kebijakan Dari Parameter Peraturan}

Ditinjau dari indikator kebijakan dari sisi parameter peraturan, pulau-pulau wisata yang dikelola oleh swasta menerapkan wisata masal, hal ini bisa dilihat dari indikator peraturan (pengawasan, kuantitas aturan, idiologi, tekanan, pemilik). Kelima elemen tersebut memiliki karakter dimana jumlah aturan yang dibuat sangat sedikit untuk memberikan keleluasaan pada perusahaan swasta, aturan yang dibuat mendukung sistem 
pasar bebas, jumlah aturan yang dibuat sedikit sekali, adanya tekanan ekonomi terhadap aturan yang ada, dan kepemilikan dalam pembangunan wisata didominasi oleh pemilik non lokal. Kontrol pemerintah dan masyarakat terhadap aturan pembangunan wisata di pulau yang dikelola oleh swasta sangat lemah. Pengelolaan pulau yang dikelola oleh swasta ini diberikan oleh pemerintah ke penyewa swasta saat perjanjian penyewaan pulau. Biasanya pulau-pulau tersebut disewakan untuk pembangunan wisata dan perikanan budidaya.

Penyewa pulau wajib mematuhi aturan yang ditetapkan oleh pemerintah, terutama masalah tujuan pengelolaan pulau. Jika pengelola pulau tersebut menyalahi aturan yang ditetapkan oleh pemerintah, misalnya dalam perjanjian sewa menyewa, pulau tersebut ditujukan untuk pengelolaan wisata, namun pada kenyataannya pulau tersebut ditujukan untuk kegiatan lain, maka pemerintah bisa mencabut izin pengelolaan pulau tersebut. Namun pada kenyataannya, fungsi pemerintah dalam melakukan pengawasan pulau sangat lemah sekali, karena keterbatasan anggaran dan sumber daya manusia. Selain itu, masalah besar di Indonesia adalah banyaknya petugas pengawas hukum yang bisa disuap oleh para pelanggar hukum.

Pada kenyataannya, pada pulau-pulau yang dikelola oleh swasta adalah dominasi peran swasta dalam. Pada Tabel 7 dapat dilihat penentuan pengelolaan pulau, peran pemerintah dalam penegakan aturan sangat lemah sekali. Misalnya penetapan harga tarif masuk yang bagi turis lokal sangat mahal sekali, akhirnya harga tarif masuk yang tinggi ini membatasi turis lokal untuk menikmati keindahan Kepulaun Seribu. Pada

Tabel 7. Indikator Kebijakan Wisata Masal Dari Parameter Peraturan.

Table 7. Mass Tourisme Policy Indicator From Rule Parameter.

\begin{tabular}{|c|c|c|c|c|}
\hline $\begin{array}{l}\text { Elemen I } \\
\text { Element }\end{array}$ & $\begin{array}{l}\text { Karakter dari } \\
\text { wisata masal / } \\
\text { Mass Tourism } \\
\text { Character }\end{array}$ & $\begin{array}{l}\text { Pulau-pulau wisata } \\
\text { yang dikelola oleh } \\
\text { swasta /Island } \\
\text { Managed by } \\
\text { Private Company }\end{array}$ & $\begin{array}{l}\text { Pulau-pulau wisata } \\
\text { yang dikelola } \\
\text { oleh masyarakat / } \\
\text { Island Managed by } \\
\text { Community }\end{array}$ & $\begin{array}{c}\text { Pulau-pulau wisata yang } \\
\text { dikelola oleh pemerintah/ } \\
\text { Island Managed by } \\
\text { Goverment }\end{array}$ \\
\hline $\begin{array}{l}\text { Kontrol/ } \\
\text { Control }\end{array}$ & $\begin{array}{l}\text { Peraturan dikontrol } \\
\text { oleh sektor swasta/ } \\
\text { Law controlled by } \\
\text { private sector }\end{array}$ & $\begin{array}{l}\text { Peraturan dikontrol } \\
\text { oleh sektor swasta/ } \\
\text { Law controlled by } \\
\text { private sector }\end{array}$ & $\begin{array}{l}\text { Peraturan dikontrol } \\
\text { oleh masyarakat } \\
\text { lokal/ Law controlled } \\
\text { by community }\end{array}$ & $\begin{array}{l}\text { Peraturan dikontrol oleh } \\
\text { pemerintah/ Law controlled } \\
\text { by goverment }\end{array}$ \\
\hline $\begin{array}{l}\text { Kuantitas/ } \\
\text { Quantity }\end{array}$ & $\begin{array}{l}\text { Aturan yang dibuat } \\
\text { mengakomodasi } \\
\text { kepentingan } \\
\text { swasta/ Rules just } \\
\text { accommodate the } \\
\text { private interests }\end{array}$ & $\begin{array}{l}\text { Aturan yang dibuat } \\
\text { mengakomodasi } \\
\text { kepentingan } \\
\text { swasta/ Rules just } \\
\text { accommodate the } \\
\text { private interests }\end{array}$ & $\begin{array}{l}\text { Aturan yang dibuat } \\
\text { mengakomodasi } \\
\text { kepentingan } \\
\text { masyarakat } \\
\text { lokal/ Rules just } \\
\text { accommodate the } \\
\text { community interests }\end{array}$ & $\begin{array}{l}\text { Aturan yang dibuat } \\
\text { mengakomodasi } \\
\text { kepentingan masyarakat } \\
\text { lokal dan pemerintah/ } \\
\text { Rules just accommodate } \\
\text { the government and local } \\
\text { interests }\end{array}$ \\
\hline $\begin{array}{l}\text { Prinsip / } \\
\text { Principle }\end{array}$ & $\begin{array}{l}\text { Menganut idiologi } \\
\text { pasar bebas(input/ } \\
\text { output)/ Market free } \\
\text { ideology }\end{array}$ & $\begin{array}{l}\text { Menganut idiologi } \\
\text { pasar bebas(input/ } \\
\text { output)/Market free } \\
\text { ideology }\end{array}$ & $\begin{array}{l}\text { Menganut idiologi } \\
\text { pasar bebas(input/ } \\
\text { output)/Market free } \\
\text { ideology }\end{array}$ & $\begin{array}{l}\text { Menganut idiologi pasar } \\
\text { bebas (input/output)/ } \\
\text { Market free ideology }\end{array}$ \\
\hline $\begin{array}{l}\text { Penekanan/ } \\
\text { Attention }\end{array}$ & $\begin{array}{l}\text { Aturan berorientasi } \\
\text { pada pertumbuhan } \\
\text { ekonomi / Rule- } \\
\text { oriented economic } \\
\text { growth }\end{array}$ & $\begin{array}{l}\text { Aturan berorientasi } \\
\text { pada pertumbuhan } \\
\text { ekonomi/ Rule- } \\
\text { oriented economic } \\
\text { growth }\end{array}$ & $\begin{array}{l}\text { Aturan berorientasi } \\
\text { pada pertumbuhan } \\
\text { ekonomi lokal/ Rule- } \\
\text { oriented economic } \\
\text { local growth }\end{array}$ & $\begin{array}{l}\text { Aturan berorientasi pada } \\
\text { pertumbuhan ekonomi } \\
\text { lokal dam menjaga } \\
\text { bangunan bersejarah/ } \\
\text { Rule-oriented economic } \\
\text { local growth }\end{array}$ \\
\hline $\begin{array}{l}\text { Pemilik/ } \\
\text { Owner }\end{array}$ & $\begin{array}{l}\text { Pemilik perusahan } \\
\text { besar non lokal/ } \\
\text { Owner is big non } \\
\text { local company }\end{array}$ & $\begin{array}{l}\text { Pemilik perusahan } \\
\text { besar non lokal/ } \\
\text { Owner is big non } \\
\text { local company }\end{array}$ & $\begin{array}{l}\text { Pemilik perusahan } \\
\text { masyarakat lokal } \\
\text { dalam skala kecil/ } \\
\text { Owner is small } \\
\text { local company }\end{array}$ & $\begin{array}{l}\text { Dimiliki oleh pemerintah } \\
\text { dan masyarakat lokal/ } \\
\text { Owner is goverment }\end{array}$ \\
\hline $\begin{array}{l}\text { Kesimpulan/ } \\
\text { Conclusion }\end{array}$ & & $\begin{array}{l}\text { Wisata masal/ Mass } \\
\text { tourism }\end{array}$ & $\begin{array}{l}\text { Wisata non-masal/ } \\
\text { Non-mass tourism }\end{array}$ & $\begin{array}{l}\text { Wisata non-masal/ Non- } \\
\text { mass tourism }\end{array}$ \\
\hline
\end{tabular}

Sumber : Pengamatan, Wawancara dan Analisa Peneliti, 2012

Source : Observation, Interview and Data Processed, 2012 
kenyataannya adalah keindahan pulau tersebut banyak dinikmatin oleh turis asing. Pemerintah tidak bisa ikut campur dalam penentuan harga tiket masuk, karena menurut pemerintah harga itu ditentukan oleh permintaan, jika permintaan tinggi maka harganya akan naik. Padahal dalam tahap awal perjanjian sewa menyewa, penduduk lokal harus diberi akses terhadap Kepulauan Seribu.

Berbeda dengan pulau-pulau yang dikelola oleh pemerintah dan masyarakat lokal, dari sisi indikator kebijakan peraturan, pulau-pulau ini tidak menerapkan wisata masal. Hal ini bisa dilihat dari tidak ada satu pun elemen wisata masal eksis, dimana peraturan wisata dikontrol oleh pemerintah dan masyarakat lokal, dan kepemilikan homestay atau restoran berasal dari penduduk lokal. Namun ada kelemahanya dalam pelaksanaan, dimana antara pelaksanaan dan perencenaan sering tidak sesuai. Misalnya, Pulau merupakan pulau yang terletak di wilayah konservasi, berarti pengelolaan wisata di pulau tersebut harus dibatasi. Namun pada kenyataannya, setiap tahun ada 9.600 penyelam yang melakukan aktivitas menyelam di pulau tersebut. Padahal menurut daya dukung lingkungan, hanya boleh $5.000-6.000$ orang. Lagi pula, pulau yang dikelola oleh masyarakat selain ditujukan untuk pemukiman, juga untuk wisata, setiap tahun ada peningkatan jumlah penginapan di Pulau yang dikelola oleh masyarakat.

\section{PENUTUP}

Di Kepulauan Seribu, terutama di pulaupulau yang dikelola oleh swasta ada beberapa indikator kebijakan dari pembangunan wisata masal yang diterapkan. Kebijakan pembangunan wisata masal ini dikuatirkan tidak sesuai dengan karakteristik wilayah Kepulauan Seribu yang terdiri dari pulau-pulau kecil yang sangat rentan terhadap perubahan lingkungan. Implikasi kebijakan pada pembangunan wisata masal adalah terlalu komersial, mengabaikan aspek sosial seperti keterlibatan masyarakat, hanya berorientasi pada peningkatan jumlah pengunjung.

Pembangunan yang berorientasi pada peningkatan jumlah pengunjung sangat bertentangan dengan prinsip-prinsip pembangunan berkelanjutan. Orientasi ini banyak dilakukan pada pulau-pulau yang dikelola swasta karena pengelola ingin modal yang diinvestasikan kembali dalam waktu cepat. Pengelola pulau telah mengivestasikan banyak modal untuk pembangunan infrastruktur pulau, seperti darmaga, jalan, hotel, kolam renang, dan lain-lain. Implikasi lain dari kebijakan pembangunan wisata masal pada pulau yang dikelola oleh swasta adalah banyak pengunjung non lokal (asing) dan domestik dari kalangan atas yang berkunjung ke pulau yang dikelola swasta ini disebabkan biaya yang cukup tinggi untuk berkunjung, dimana turis lokal tidak mampu membayarnya.

Implikasi lainnya darikebijakan pembangunan wisata masal adalah sektor wisata mendominasi perekonomian di pulau yang dikelola swasta, dimana dilakukan secara ektensif akan tetapi multiplier effect-nya sedikit sekali karena kurangnya keterlibatan masyarakat. Sebaliknya pulau yang dikelola oleh masyarakat dan pemerintah kurang mengaplikasi indikator pembangunan wisata masal. Dari hasil analisis pengelolaan wisata masal atau tidak masal dari penelitian ini, terlihat bawah semua pulau yang dikelola oleh perusahaan swasta, menerapkan wisata masal, baik dilihat dari parameter pasar, atraksi, penginapan, struktur ekonomi, dan aturan. Padahal jika dilihat dari karakteristik kepulauan Seribu yang terdiri dari gugusan pulaupulau kecil yang sangat rawan terhadap perubahan lingkungan, maka pengembangan wisata masal tidak cocok untuk kepulauan ini, harusnya pulaupulau kecil di Kepulauan Seribu harus dikelola dengan menerapkan prinsip-prinsip wisata yang berkelanjutan.

\section{DAFTAR PUSTAKA}

Bardole, E. dan P. Serdone. 2008. Tourism In Archipelagos: Hawai'i and the Balearics. Annals Of Tourism Research 35 (4): 900-923.

Cournayer, N. 2005. Le Tourisme De Masse Durable. Sciences De La Gestion.

Fly, H. R., N. Couzens dan G. Wilson. 2008. Measuring the Environmental Impact of Travel: Business Intelligence for Informed Travel Choice. The Travel \& Tourism Competitiveness Report 2008. World Economic Forum.

Shaw, G. dan A. M. Williams. 2002. Critical Issues in Tourism: A Geographical Perspective,

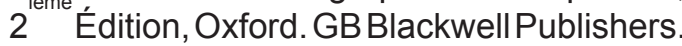

Sorupia, E. 2005. Rethingking the Role of Transportation in Tourism. Proceedings of the Eastern Asia Society for Transportation Studies 5: 1767 - 1777. Faculty of Architecture, Building and Planning. The University of Melbourne. 
Stock, M., O. Dehornee dan P. Duhamel. 2006. Le tourisme, Acteurs, Lieux, Et enjeux. La Géographie aux édition belin.

UNWTO. 2005. Tourism Highlights. United Nations World Tourism Organization.

Uyarra, M. C., A. R. Watkinson dan I. M. Cote. 2009. Managing Dive Tourism for The Sustainable Use of Coral Reefs. Environment and Management Journal 43 (2):1-16.
Weaver, D. 1991. Alternative to Mass Tourism in Dominica. Pegamon Press.

Weaver, D. B. 2000. A Broad Context Model of Destination Development Scenarios. Tourism Management 21 (3). 